\title{
Asymmetric and Non-Linear Adjustments in Local Fiscal Policy
}

\author{
GABRIELLA LEGRENZI
}

CESIFO WORKING PAPER NO. 2550

CATEgORY 1: Public FinANCE

FEBRUARY 2009

\footnotetext{
An electronic version of the paper may be downloaded

- from the SSRN website: www.SSRN.com

- from the RePEc website: - from the CESifo website: 


\title{
Asymmetric and Non-Linear Adjustments in Local Fiscal Policy
}

\begin{abstract} taxation, pointing to a budget-maximising local government.

JEL Code: H10, H71, C22.

\author{
Gabriella Legrenzi \\ Department of Economics \\ School of Economic and Management Studies \\ Keele University \\ Staffordshire, ST5 5BG \\ United Kingdom \\ g.d.legrenzi@keele.ac.uk
}

We analyse the revenue-expenditure patterns of local governments, allowing for asymmetric and non-linear adjustments of local spending and taxation to disequilibrium errors. Our results provide evidence of a downward inflexibility of both local government spending and local

Keywords: fiscal federalism, fly-paper effect, non-linear time-series, asymmetric adjustment.

February 13, 2009

A former version of this paper has been presented at the North American Summer Meeting of the Econometric Society, at the annual meeting of the European Public Choice Society, and at the annual congress of the International Institute of Public Finance. I would like to thank the participants and discussants for their useful feedback. The usual disclaimer applies. 


\section{Introduction}

The focus on fiscal federalism and the potential role of local governments in disciplining an excessive growth of public expenditure, has considerably increased in the recent years, following a remarkable growth of the public sector in industrialized countries. The debate on fiscal federalism is even more pressing for the European Monetary Union member countries, given the budgetary constraints they are subject to.

Traditional public finance analysis emphasizes the advantages of fiscal decentralization, as local governments have an informational advantage on central governments with respect to local costs and demand conditions, allowing them, under some conditions, to better satisfy local demands and deliver public services at a lower cost for public funds (see on this, Oates 1972, 1999). On the other hand, second generation models of fiscal federalism point to the existence of conflicting objectives between local and central governments, casting some doubts on the effectiveness of fiscal decentralisation (Oates, 2005). Besley and Coate (2003), in particular, introduce a political economy model where the conflict of interests between central and local administrations results in excessive spending by local governments. The soft-budget constraint of local governments is also analysed in Kornai et al. (2003).

In the light of the discussion above, it becomes very important to analyse more in detail the relationships among the spending and taxing decisions of local governments and the level of transfers received from higher levels of government. For this purpose, the empirical analysis on the revenues-expenditure patterns of local governments is traditionally based on the implicit assumption of symmetry: e.g. local expenditure is expected to increase and decrease symmetrically 
following changes in unconditional transfers received and own resources. To the best of our knowledge, very few studies have considered possible asymmetries and non-linearities in local fiscal policy, as in Gamkar and Oates (1996), Stine (1994) and Heyndels (2001).

Using annual time-series data for Italian municipalities, our paper examines the relationship between local revenues and expenditures in a non-linear framework. The analysis of Italy is of particular interest, not only because Italy is an EMU country, but also because it introduced some important reforms, where the country initially strenghtened its centralisation process, only to subsequently enhance the delegation of spending powers to local authorities.

There are two main differences between our paper and the studies mentioned above. First, we use the Johansen $(1988,1995)$ multivariate cointegration technique, which allows for long-run properties and short-run dynamics of local expenditure, taxation and state transfers to be jointly analyzed, allowing for possible endogeneity of the variables ${ }^{1}$. Second, we allow for asymmetric and non-linear adjustment to disequilibrium deviations of the fiscal variables from their equilibrium levels, following the methodology introduced by Escribano and Granger (1998).

We find evidence of a "strong" fly-paper effect, in the form of a high transferelasticity of local spending, associated with an insignificant long-run effect of local taxation. This means that local spending is ultimately driven only by the size of transfers received, regardless of the ability of local governments to raise revenues from their own resources.

The adoption of non-linear modelling allows us to report asymmetric ad-

\footnotetext{
${ }^{1}$ Knight (2002) argues that transfers are the result of a political bargaining process and therefore should be considered as endogenous.
} 
justment, in the form of downward inflexibility of both local expenditure and taxation. When local expenditure is below its equilibrium level with transfers, it raises relatively fast, while when it is below, its reduction is not statistically significant. In the case of municipal taxation, taxes raise faster when they are below their equilibrium level, than they reduce when they are above.

Our empirical results therefore point to the existence of a budget-maximising local government, questioning the opportunity of further delegation of spending powers to local governments, when unaccompanied by a corresponding increase in their fiscal responsibility and control over local spending.

The paper is organized as follows; the next section presents a short survey of the economic literature on the local revenue-expenditure models. Section 3 estimates the long-run relationships among local expenditure, transfers and taxes whereas section 4 reports the short-run equations allowing for asymmetric and non-linear adjustment. Finally, section 5 provides some concluding remarks and suggestions for further research.

\section{Local Revenue-Expenditure Models and the Fly-Paper Effect.}

Traditional economic literature on the revenue-expenditure patterns of local governments has emphasised the existence of a "fly-paper" effect ${ }^{2}$. The fly-paper effect refers to the empirical regularity that the transfers-elasticity of local expenditure is higher than its own-resources elasticity. It is important to consider that the fly-paper effect is not an anomaly ${ }^{3}$ within the rational choice, as argued by Hines-Thaler (1995), but, instead, it is a signal that local and central

\footnotetext{
${ }^{2}$ The term "flypaper" is derived from the well-known remark by Arthur Okun that "money sticks where it hits".

${ }^{3}$ See on this Roemer and Silvestre, 2002.
} 
governments might have different (and potentially conflicting) objectives. This happens because fiscal discipline at a general government level has the characteristics of a non-excludable public good ${ }^{4}$. As a consequence, there is a common pool problem where local governments are incentived to overspend, to promote the interests of the local citizens/taxpayers, in the case of a responsive government, or of their elected politicians/bureaucrats in the case of a Leviathan-type of government ${ }^{5}$.

The costs of the fly-paper effect (state transfers to cover local fiscal unbalances, given the soft-budget constraint of local governments) will be shared at a national level, while its advantages will be internalized by the single jurisdictions. If the fly-paper holds, delegation of spending powers to local jurisdictions, unaccompanied by a corresponding increase in their fiscal responsibilities, will have the effect of expanding rather than contracting public sector size (Legrenzi 2000, Milas-Legrenzi 2002), as local governments are incentived to free-ride on the national fiscal discipline.

The fly-paper effect has received considerable empirical support in the literature (Hines and Thaler 1995), but has generally being analysed under the assumption of symmetry.

Under the hypothesis of symmetry, the local government reduces its expenditures in response to reductions in transfers received, whereas in the presence of asymmetries, the local government might decide to enhance its capacity to raise revenues, in order to keep unchanged the level of local expenditure. This is the so-called positive fiscal replacement hypothesis, and it is empirically supported

\footnotetext{
${ }^{4}$ At a general government level, the fiscal discipline can be identified in the compliance to Maastricht and Amsterdam criteria for the EMU, while at a local level there is no such definition, although a local balanced budget would be desirable to achieve the nation's budgetary objectives.

${ }^{5}$ For further information on the distinction between "responsive" and "excessive" government, see Buchanan (1977) and Legrenzi and Milas (2002).
} 
by Gramlich (1987), for the US. On the other hand, Paine and Stine (1994) identify a "super flypaper" effect for a panel of Pennsylvania counties: when grants are cut, own revenues also fall, resulting in a negative fiscal replacement. The findings of Gamkar and Oates (1996) for the US suggest that the flypaper effect operates in both directions, providing no support in favor of asymmetric behavior.

On the other hand, non-linearities may arise if the fiscal authorities react differently to deviations of state transfers from their equilibrium level. For instance, the local authorities may be more willing to raise taxes rapidly when they are below their equilibrium level with respect to transfers, rather than lowering taxes rapidly when these are above their long-run level.

In the context of the European Stability and Growth Pact, testing for asymmetries and non-linearities in the revenue-expenditure models becomes increasingly important for economic policy purposes, in order to evaluate reforms in the transfer system and the effectiveness of decentralization in constraining the growth of government spending.

\section{The Empirical Model.}

We base our empirical analysis on the Italian municipalites. Italy is a member country of the European Monetary Union with a typically high level of public debt (around $122 \%$ of GDP in 2006), a high deficit (4.6\% of GDP in $2006^{6}$ ), for which the control of public spending is particularly important. Increasing the authonomy of local governments is highly debated in the political arena, as a possible solution to constrain public expenditure growth. The financing of

\footnotetext{
${ }^{6}$ The data on the Italian deficit and debt are taken from the 2005 Annual Report of the Italian Central Bank (Banca d'Italia).
} 
local expenditure is heavily reliant on transfer-financing from the state, and the Italian Constitution links the levels of transfers granted to local governments to their "financing needs".

Italian municipalities are the lowest level of local government in Italy, being therefore closer both to the local preferences and the local costs conditions, with respect to the central government. They enjoy some degree of fiscal autonomy, setting their own property taxes, and are responsible for the local public services provision (transport and public utilities) ${ }^{7}$. Another advantage deriving from the choice of the Italian municipalities derives from the policy switches in their fiscal autonomy. The 1973 reform limited the taxing powers of the Italian municipalities, on the grounds of the higher efficiency of a centralised tax collection system. On the other hand, the reforms of the 1990s enhanced the taxing powers of municipalities, increasing their autonomy, on the belief that this would help constraining the public expenditure and help the country to respect the EMU requirements ${ }^{8}$. An Internal Stability Pact was introduced in 1999, requiring to extend to local governments the European Stability Pact requirements, in the annual Budget Law. ${ }^{9}$

Our sample consists of annual observations over the $1955-2003^{10}$ period, and is taken from the Italian official statistics from ISTAT, in real terms. $G$ measures the expenditures of the Italian municipalities, $T R$ the transfers received from higher levels of government, and $T A X$ the municipal taxation.

All the variables are expressed in logs. We chose annual data on the grounds of the annual frequency of the budgetary choices of local governments. Higher

\footnotetext{
${ }^{7}$ For more detailed information on the competencies of the Italian municipalities, see Legrenzi (2000).

${ }^{8}$ For further information and analysis on the Italian reforms, see OECD (2005).

${ }^{9}$ For a critical review on the reforms of the Italian fiscal federalism, see Bordignon (2004).

${ }^{10}$ The year 2003 is the latest available in the national statistics. The data from 2001 onwards are nevertheless provisional.
} 
frequency data will give us more degrees of freedom, but, nevertheless, will bias the analysis, given the annuality of the municipal budgets ${ }^{11}$.

Levels and first differences of the variables are plotted in Figure 1.

Preliminary analysis of the time-series properties of the data suggested that all variables are non-stationary in levels ${ }^{12}$. Given the possible endogeneity among the variables in question, we employ the Johansen approach to cointegration. Following Johansen $(1988,1995)$, we write a p-dimensional vector error correction model as:

$$
\Delta y_{t}=\sum_{i=1}^{k-1} \Gamma_{i} \Delta y_{t-1}+\Pi y_{t-1}+\mu+\varepsilon_{t}
$$

where $y_{t}=[G, T R, T A X]$ is the set of non-stationary $\mathrm{I}(1)$ variables discussed above, $\varepsilon_{t} \sim \operatorname{niid}(0, \Sigma), \mu$ is a drift parameter, and $\Pi$ is a $(p * p)$ matrix of the form $\Pi=\alpha \beta^{\prime}$, where $\alpha$ and $\beta$ are $(p * r)$ matrices of full column rank, with $\beta$ containing the $\mathrm{r}$ cointegrating vectors and $\alpha$ carrying the corresponding loadings in each of the $\mathrm{r}$ vectors.

Allowing for an unrestricted intercept term and a lag length of $\mathrm{k}=1$ in the VAR model ${ }^{13}$, Table 1 reports the $\lambda$-max and the $\lambda$-trace test statistics for cointegration together with their corresponding $95 \%$ critical values (calculations are done in Microfit 4.1; see Pesaran and Pesaran, 1997, and in E-views 5.1). The empirical results provide evidence of two cointegrating vectors, which is stronger for the $\lambda$-max rather than the $\lambda$-trace statistic. We consequently proceed by assuming the existence of two cointegrating vectors. For exact iden-

\footnotetext{
${ }^{11}$ A further difficulty arises since the municipal fiscal year does not coincide with the calendar year, which forms the basis of the municipal data collection.

12 Results are available on request.

${ }^{13}$ The $\mathrm{k}=1$ is chosen by both the Schwarz information criterion and by the Hannan-Quinn information criterion. The Akaike would have supported a lag lenght of 3 . Given the small sample considered, we set $\mathrm{k}=1$ to avoid the loss of too many degrees of freedom.
} 
tification we impose a unit coefficient on municipal expenditure $\left(\beta_{11}=1\right)$ and a zero coefficient on taxes $\left(\beta_{13}=0\right)$ in the first vector, and a unit coefficient on municipal taxation $\left(\beta_{23}=1\right)$ and a zero coefficient on municipal expenditure $\left(\beta_{21}=0\right)$ in the second one. These restrictions are justified on the grounds that, given the possibility of one cointegrating vector based on the $\lambda$-trace statistics, we also normalized on $G$ and tested for zero long-run effects from taxes within one cointegrating vector. This hypothesis was not rejected at conventional levels of statistical significance ${ }^{14}$. This result motivates the exclusion of taxes from the first cointegrating vector as a valid identifying restriction. We have also tested for weak exogeneity of transfers for the rest of the system. This is a test on the adjustment (alpha, $\alpha$ ) coefficient on TR in the two cointegrating vectors. The test is a Likelihood Ratio (LR) test distributed as a $\chi^{2}(2)$ under the null, giving a value of 4.204 , which is insignificant at the 5 percent level $(\mathrm{p}$-value $=$ 0.122). In statistical terms, weak exogeneity of transfers implies that we can proceed by estimating short-run equations for $G$ and $T A X$ conditioning on $T R$ without loss of any significant information. In economic terms, conditioning on transfers has the interpretation that within current local government fiscal policy decision-making, state transfers are exogenous, confirming our normalization choice.

Imposing the restrictions discussed above yields the following restricted cointegrating vectors:

$$
G=0.71 T R(\text { s.e. }=.02)
$$

and

\footnotetext{
${ }^{14}$ Results are available on request.
} 


$$
T A X=0.50 T R(\text { s.e. }=.03)
$$

The highly positive coefficient of transfers in the first vector confirms the existence of a fly-paper effect: a $10 \%$ increase in state transfers raises municipal expenditure by $7 \%$. The irrelevance of municipal taxation in determining local expenditure represents a peculiarity of the Italian municipalities, which we consider to be a "strong" version of the fly-paper effect. This means that the long-run equilibrium values of local expenditure are entirely driven by the level of transfers received from higher levels of government.

The second cointegrating vector describes the relationship between local taxation and state transfers. Local taxation in the long-run is expected to increase by $5 \%$ in response to a $10 \%$ increase in state transfers. This means that increases in state transfers do not bring tax relief to the community. In addition to the long-run analysis, further useful insight to understand the spending and taxing decisions of the Italian municipalities is provided in the short-run analysis below.

\section{Short-run adjustments of local taxes and spend- ing.}

Having verified the existence of a long-run equilibrium among the local fiscal policy variables, we model their short-run adjustments conditioning on transfers. The two cointegrating vectors given by equations (2) and (3) above are denoted by $\mathrm{CV}_{1}$ and $\mathrm{CV}_{2}$, respectively. We initially estimate a linear error-correction model for local expenditure and local taxation and subsequently test for possible non-linearities. In case where the null of linear adjustment is rejected, we proceed by estimating non-linear error-correction models. 
Various authors have examined non-linearities in the behavior of error correction models (see e.g. Granger and Lee, 1989; Escribano and Pfann, 1998; Escribano and Granger 1998; and Escribano and Aparicio, 1999, among others). In particular, Granger and Lee (1989) partition the error correction term into its positive and negative components, and feed them back into the short-run dynamic equation. The idea here is to test for different speed of adjustments depending on whether the fiscal variables are above or below their unique (at the zero point) equilibrium. However, imposing a unique equilibrium around zero may be too restrictive. In order to relax this assumption, Escribano and Granger (1998) and Escribano and Aparicio (1999) among others, use a cubic error correction term. This type of nonlinear adjustment is more flexible than the Granger and Lee (1989) type of asymmetric adjustment as it allows for the possibility of more than one equilibrium point. This type of non-linear adjustment also allows for a faster adjustment when deviations from the equilibrium level get larger.

\subsection{Short-run adjustments of municipal expenditure.}

We initially estimate the error correction model on the assumption of linear response of municipal expenditure with respect to increases and decreases of State transfers from their equilibrium value. The model estimated is therefore:

$$
\Delta G_{t}=C+\beta_{1} \Delta T A X_{t}+\beta_{2} \Delta T R_{t}+\beta_{3} C V_{t-1}^{1}+u_{t}
$$

We also considered an EMU dummy, taking the value of 1 from 1993 onwards, to capture the impact of the European Monetary Union, and a centralisation dummy, taking the value of 1 between 1973 and 1990, to capture the centralisation of tax collection under the 1973 reform. The Internal Stability Pact 
is captured by a dummy taking the value of 1 from 1999 onwards. All these variables were statistically insignificant in all models.

Regression results are reported in Table 2(i). The linear model is rather poor, failing most of the diagnostic tests. This might be due to omitted nonlinearities. To detect this, we initially test for linearity in the residuals of the error correction model. We apply the well known Brock, Dechert and Sheinkman (1996, thereafter BDS) test statistic. Under the null hypothesis of linearity in the residuals, the BDS test follows the normal distribution whereas rejection of the null implies an unspecified non-linear structure ${ }^{15}$. Based on the p-values associated with the BDS test, the results in Table 3 suggest the presence of non-linear structure in the residuals of the error correction model.

Table 2 (columns (ii) and (iii)) reports the error correction equation based on different types of non-linear adjustment. First, as in Granger and Lee (1989), we take the deviations of lagged $\mathrm{CV}_{1}$ around its mean value, and partition them into their positive and negative components (denoted by $\mathrm{CV}_{1}^{+}$and $\mathrm{CV}_{1}^{-}$, respectively). Then, as in Escribano and Granger (1998) and Escribano and Aparicio (1999), we estimate a cubic error correction model. More specifically, we allow for lagged $\mathrm{CV}_{1}^{2}$ and $\mathrm{CV}_{1}^{3}$ to enter the short-run equation. The asymmetric model takes the form:

$$
\Delta G_{t}=C+\theta_{1} \Delta T A X_{t}+\theta_{2} \Delta T R_{t}+\theta_{3} C V_{1, t-1}^{+}+\theta_{4} C V_{1, t-1}^{-}+z_{t}
$$

The non-linear model takes the form:

$$
\Delta G_{t}=C+\gamma_{1} \Delta T A X_{t}+\gamma_{2} \Delta T R_{t}+\gamma_{3} C V_{1, t-1}+\gamma_{4} C V_{1, t-1}^{2}+\gamma_{5} C V_{1, t-1}^{3}+e_{t} \text { (6) }
$$

\footnotetext{
${ }^{15}$ Several non-linearity tests exist in the literature. However, as Ashley and Patterson (2001, p.20) point out, the BDS test is the best among different tests for use as a non-linearity screening test.
} 
The results in Table 2(ii) show the presence of an asymmetric adjustment for local expenditure that relies on a downward inflexibility of this fiscal policy variable. Indeed, the coefficient associated with the lagged value of $\mathrm{CV}_{1}^{+}$is statistically insignificant. This means that when local expenditure is below its equilibrium level with state transfers, it increases relatively fast, whereas when it is above its equilibrium, its reduction is not statistically significant.

The non-linear ECM results, in Table 2(iii), provides some evidence of possible non-linearities in the adjustment of local expenditure, given the statistical significance at a $90 \%$ confidence level of the $\mathrm{CV}_{1}^{2}$ (but not the $\mathrm{CV}_{1}^{3}$ ) regressor. Therefore, there is some evidence of a faster adjustment when deviations from the equilibrium level get larger.

Next, we plot the asymmetric and non-linear types of adjustment against $\mathrm{CV}_{1}$ (see Figure 2 and Figure 3, respectively). From Figure 2 there is evidence of asymmetric adjustment as the cross-plot is far from being a straight line. The plot of the nonlinear cubic polynomial in Figure 3 suggests the existence of asymmetric adjustment around a unique equilibrium point.

The recursive estimates of the asymmetric ECM for local spending, in Figure 6 , verify the insignificance of $\mathrm{CV}_{1}^{+}$as the estimates \pm the 2 standard error bands always include zero. On the other hand, the recursive estimates for $\mathrm{CV}_{1}^{-}$suggest that the asymmetry gets stronger over time, in the sense that the point estimate starts from around -0.18 to reach -0.25 at the end of the sample.

\subsection{Short-run adjustments of the local taxation.}

We now report the ECM model for local taxation, allowing for possible nonlinear and asymmetric behaviour. Results are reported in Table 4. As for local spending, we perform a BDS test on the residuals of the linear ECM. Based on 
the p-values associated with the BDS test, the results in Table 5 strongly suggest the presence of non-linear structure in the residuals of the error correction model for $\triangle \mathrm{TAX}$. Table 4(ii) and 4(iii) report the estimated error correction equation, based on the different types of non-linear adjustment discussed earlier. The $\mathrm{CV}_{2}^{+}, \mathrm{CV}_{2}^{-}, \mathrm{CV}_{2}^{2}$ and $\mathrm{CV}_{2}^{3}$ variables are constructed in the same way as the corresponding $\mathrm{CV}_{1}$ regressors.

The results in Table 4(ii) demonstrate the presence of an asymmetric adjustment for local taxation that relies on a downward inflexibility of this fiscal policy variable. Indeed, the coefficient associated with the lagged value of $\mathrm{CV}_{2}^{+}$(i.e. -0.01 ) is lower than the coefficient on $\mathrm{CV}_{2}^{-}$(i.e. -0.30 ), and it is also statistically insignificant. This means that when local taxes are below their equilibrium level with respect to state transfers, they increase relatively fast, whereas when they are above their equilibrium, they fall relatively slowly.

The non-linear ECM results in table 4(iii) show the existence of possible nonlinearities in the adjustment of local taxes, backed by the statistical significance of the $\mathrm{CV}_{2}^{2}$ (but not the $\mathrm{CV}_{2}^{3}$ ) regressors. Therefore there is evidence of faster adjustment when deviations from the equilibrium level get larger.

Next, we plot the asymmetric and non-linear types of adjustment against $\mathrm{CV}_{2}$ (see Figure 4 and Figure 5, respectively). From Figure 4 there is evidence of asymmetric adjustment as the cross-plot is far from being a straight line. The plot of the nonlinear cubic polynomial in Figure 5 suggests the existence of one equilibrium.

The recursively estimated coefficients of the asymetric ECM for local taxation, plotted in Figure 7, show that the effect of the asymmetry is stable over time.

Overall, our results point to some form of budget-maximising behaviour 
by the Italian local governments, that the different reforms have so far been unable to tackle. A stronger link between municipal expenditure and municipal taxation, as well as spending and transfers reforms will be needed in order for decentralisation to effectively constrain the growth of government spending in Italy.

However, some caution must be taken when interpreting the results above. The use of aggregate data has the effect of lumping together the responses of all Italian municipalities, and therefore, the estimated response could reflect some mixture of symmetric and asymmetric coefficients (Gamkhar and Oates, 1996). Further, the degree of asymmetry might also depend on some characteristics of the local jurisdictions, that cannot be captured by the aggregate data (Gamkar and Oates, 1996). Territorial distinctions can also be relevant for Italy, given the importance of state transfers to southern areas (see also OECD, 2005). On the other hand, as our main focus is on the macro-economic impact of local fiscal policy, the use of aggregate data is necessary to assess the macro-asymmetries in the local revenue-expenditure models.

\section{Conclusions}

This paper models the local revenue-expenditure relationship in the case of Italian municipalities, using both linear and non-linear cointegrating techniques.

The long-run analysis shows the absence of a direct link between local ex-

penditure and taxation, as local spending is entirely driven by the amount of transfers received by the central government. The short-run asymmetric model shows evidence of revenue-maximising behaviour by local governments, driven by the downward inflexibility of both local expenditure and taxation.

These results have important economic policy implications. First, the del- 
egation to local governments of further power to spend should be attached to a higher level of fiscal responsibility, that is linking local expenditure to local taxation, in order for local governments to face an effective budget constraint. If this were not the case, the decentralization of public expenditure might provide the undesired outcome of an expansion rather than contraction in public sector size, given the downward inflexibility of both the local fiscal policy variables.

Further, the downward inflexibility of local expenditure appears to be a relevant problem in this context, that so far has not been explicitly tackled by the different reforms, evidenced by the insignificance of the policy dummies as well by the analysis of the recursively estimated asymmetric ECM coefficients.

There are at least two possible extensions of our analysis. First, territorial and dimensional differences might be captured within a panel data model of Italian municipalities. Second, it would be interesting to introduce and estimate a two-regime smooth transition autoregression model (STAR, see e.g. Granger and Terasvirta, 1993), where adjustment takes place in every period but the speed of adjustment varies on whether disequilibrium deviations are large or small. These issues can be addressed in future research.

\section{References}

[1] Ashley, R.A. and D.M. Patterson (2001). "Nonlinear Model Specification/Diagnostics: Insights from a Battery of Nonlinearity Tests", Economics Department Working Paper E99-05, VirginiaTech.

[2] Besley T. and Coate S. (2003). "Centralized versus Decentralized Provision of Local Public Goods: a Political Economy Approach", Journal of Public Economics 87: 2611-2637. 
[3] Bordignon M. (2004), "Fiscal Decentralization: How to Harden the Budget Constraint", paper presneted st the Worksho "Fiscal Surveillance in EMU: New Issues and Challenges", Bruxelles, Novemner 2004.

[4] Brock, W.A., D.A. Hsieh and B.D. LeBaron (1991). Nonlinear Dynamics, Chaos and Instability, MIT Press, Cambridge.

[5] Brock, W.A., W. Dechert and J. Scheinkman (1996). A Test for Independence Based on the Correlation Dimension, Econometric Reviews 15: 197-235.

[6] Buchanan J.M. (1977) Budgets and Bureaucrats: The Sources of Government Growth, Duke University Press.

[7] Escribano, A. and F. Aparicio (1999). "Cointegration: Linearity, Nonlinearity, Outliers and Structural Breaks" in Dahiya, S.B. (ed), The Current State of Economic Science, Spellbound Publications, Vol 1, 383-407.

[8] Escribano, A. and C.W.J. Granger (1998). "Investigating the Relationship between Gold and Silver Prices". Journal of Forecasting 17: 81-107.

[9] Escribano, A. and G.A. Pfann (1998). "Nonlinear Error Correction, Asymmetric Adjustment and Cointegration". Economic Modelling 15: 197-216.

[10] Gamkhar S. and Oates W. (1996), "Asymmetries in the Response to Increases and Decreases in Intergovernmental Grants: Some Empirical Findings", National Tax Journal 49(4): 501-12.

[11] Gramlich E. M. (1987). "Federalism and Federal Deficit Reduction". National Tax Journal 40(3): 299-313. 
[12] Granger, C.W.J. and T.H. Lee (1989). "Investigation of Production, Sales and Inventory Relationships Using Multicointegration and Non-symmetric Error Correction Models". Journal of Applied Econometrics 4: S145-S159.

[13] Granger, C.W.J. and T. Teräsvirta (1993). Modelling Nonlinear Economic Relationships. Oxford University Press, Oxford.

[14] Heyndels B. (2001). "Asymmetries in the Flypaper Effect: Empirical Evidence for the Flemish Municipalities", Applied Economics, 33, 1329-1334.

[15] Hines J.R. and Thaler R.H. (1995), " The Fly-Paper Effect", Journal of Economic Perspectives, 9(4), pp.217-226.

[16] Johansen, S. (1988). Statistical Analysis of Cointegration Vectors. Journal of Economic Dynamics and Control: 12, 231-254.

[17] Johansen, S. (1995). Likelihood-based inference in cointegrated vector autoregressive models. Oxford University Press, Oxford.

[18] Knight B. (2002), "Endogenous Federal Grants and Crowd-Out of State Government Spending: Theory and Evidence from the Federal Highway Aid Program", American Economic Review, 92(1), 71-92.

[19] Kornai J., Maskin E. and Roland G. (2003), "Understanding the SoftBudget Constraint", Journal of Economic Literature 41(4), 1095-1136.

[20] Legrenzi G. and Milas C. (2002), "The Role of Omitted Variables in Identifying a Long-Run Equilibrium Relationship for the Italian Government Growth", International Tax and Public Finance 9(4), 435-450. 
[21] Legrenzi G. (2000), "An Empirical Analysis of the Revenue-Expenditure Patterns of the Italian Local Governments", Journal of Public Finance and Public Choice, 18, 2/3, 171-185.

[22] Oates, W. E. (2005), "Toward a Second-Generation Theory of Fiscal Federalism", International Tax and Public Finance, 12(4), 349-73.

[23] Oates W.E. (1999), "An Essay on Fiscal Federalism", Journal of Economic Literature, 37, 1120-1149.

[24] Oates W.E.(1972), Fiscal federalism, Harcourt, New York.

[25] OECD (2005). Economic surveys: Italy. Paris.

[26] Pesaran, M.H. and B. Pesaran (1997). Microfit 4.0: an interactive econometric software package, Oxford University Press, Oxford.

[27] Roemer J. and Silvestre J. (2002), "The Flypaper Effect is not an Anomaly", Journal of Public Economic Theory, 4(1), 1-17.

[28] Stine W.F. (1994), "Is Local Government Revenue Response to Federal Aid Symmetrical? Evidence from Pennsylvania County Governments in an Era of Retrenchment", National Tax Journal, 47(4), 799-816. 
Figure 1: Levels and first differences of the variables
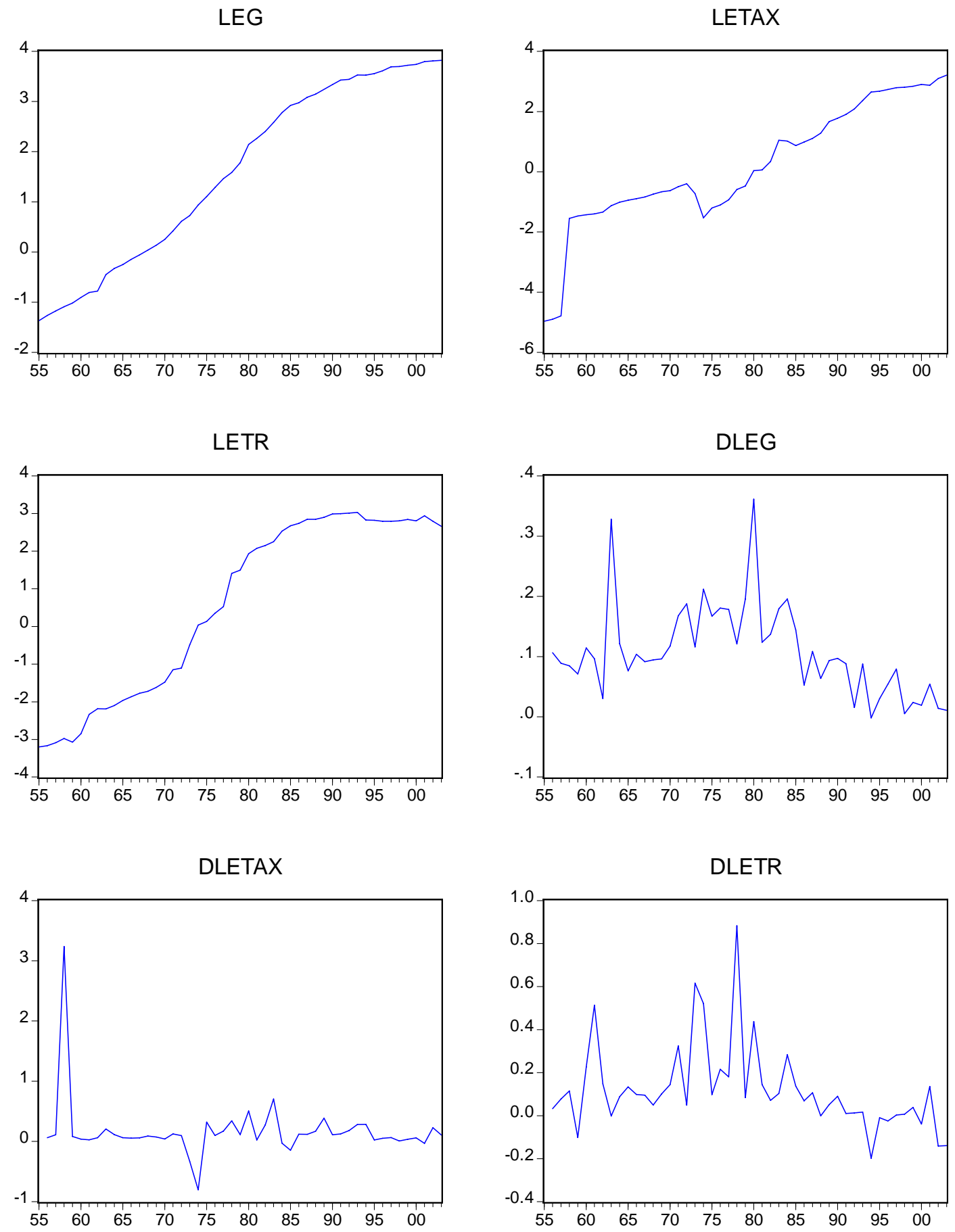
Figure 2. Asymmetric adjustment in local expenditure

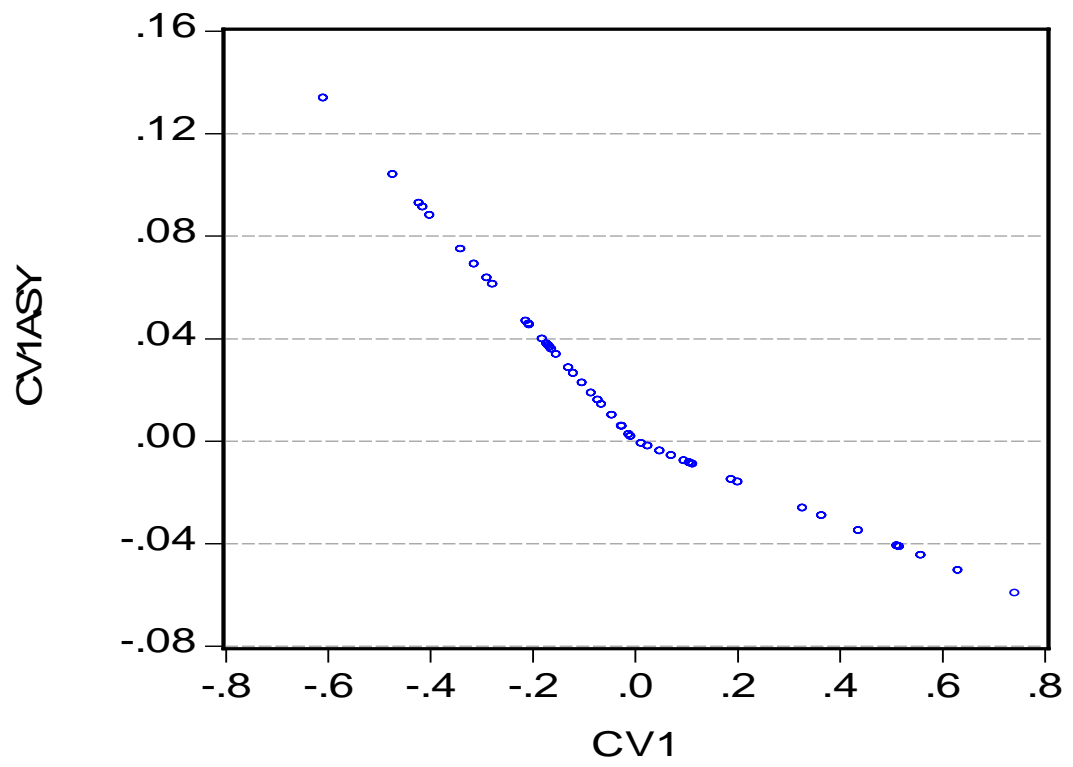

Note: CV1ASY $=-0.08 *$ CV1PLUS $-0.22{ }^{\star}$ CV1MINUS

Figure 3. Non-linear adjustment in local expenditure

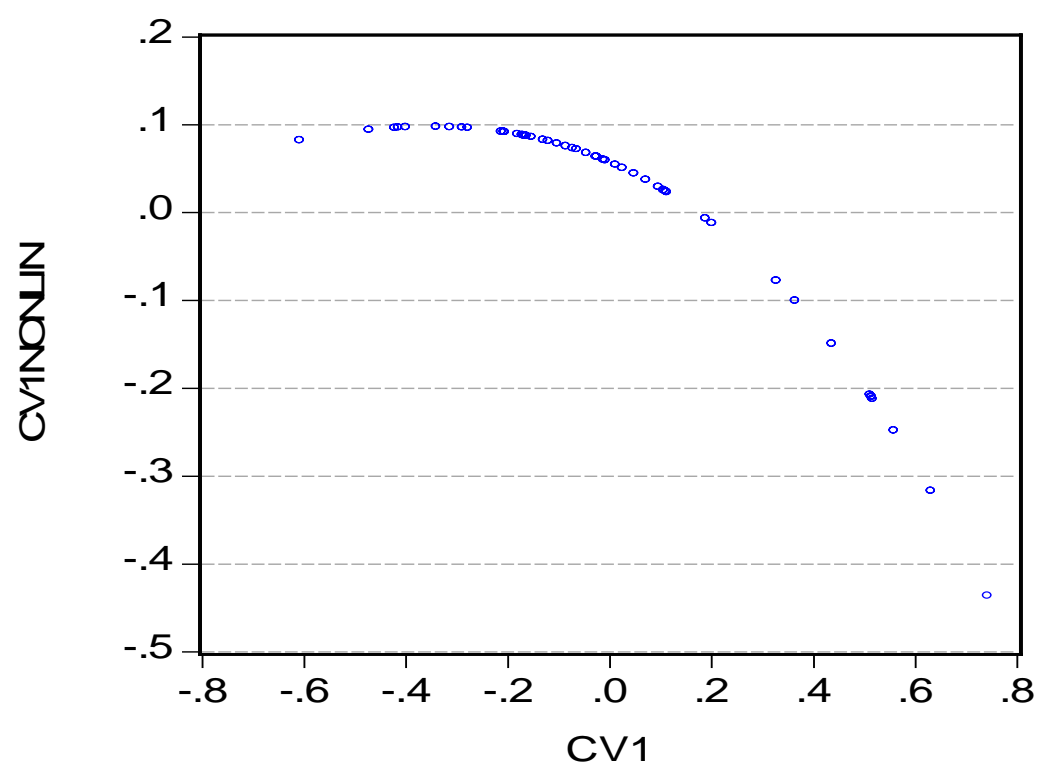

Note: CV1NONLIN $=-0.12^{\star} \mathrm{CV} 1+0.13^{\star} \mathrm{CV} 1^{2}-.16^{\star} \mathrm{CV} 1^{3}$ 
Figure 4. Recursive estimates for the asymmetric ECM for local expenditure.
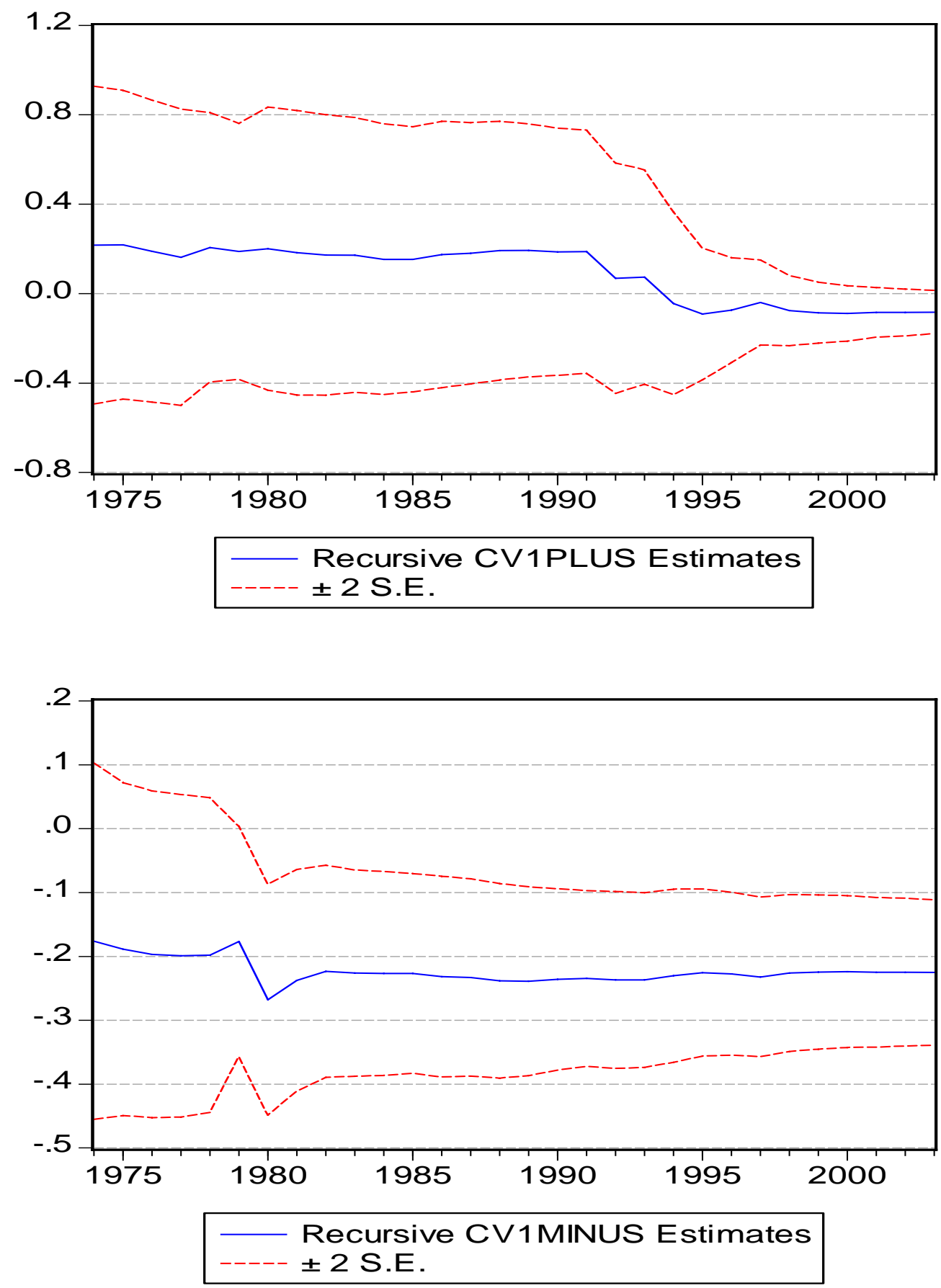
Figure 5. Asymmetric adjustment in local taxation

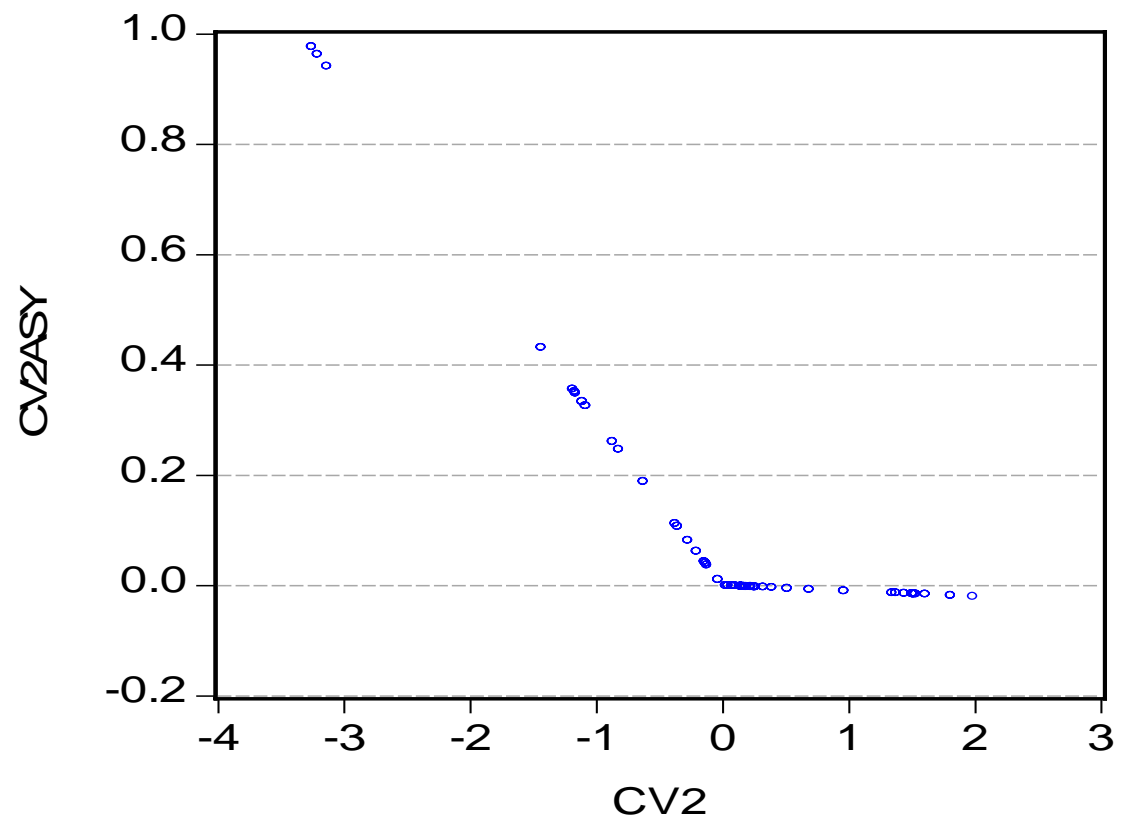

Note: CV2ASY $=-0.01 *$ CV2PLUS $-0.30^{*}$ CV2MINUS

Figure 6. Non-linear adjustment in local taxation

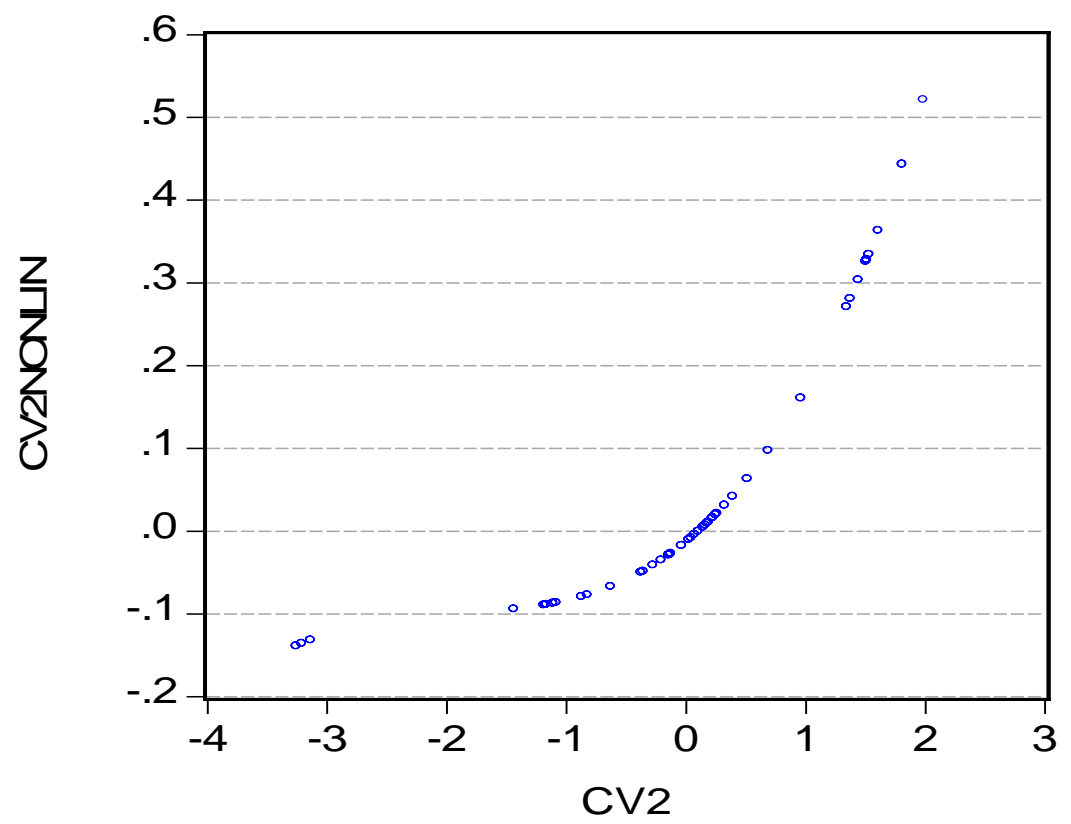

Note: CV2NONLIN $=-0.13^{\star} \mathrm{CV} 2+0.06^{\star} \mathrm{CV} 2^{2}$ 
Figure 7. Recursive estimates for the asymmetric ECM for local taxation.
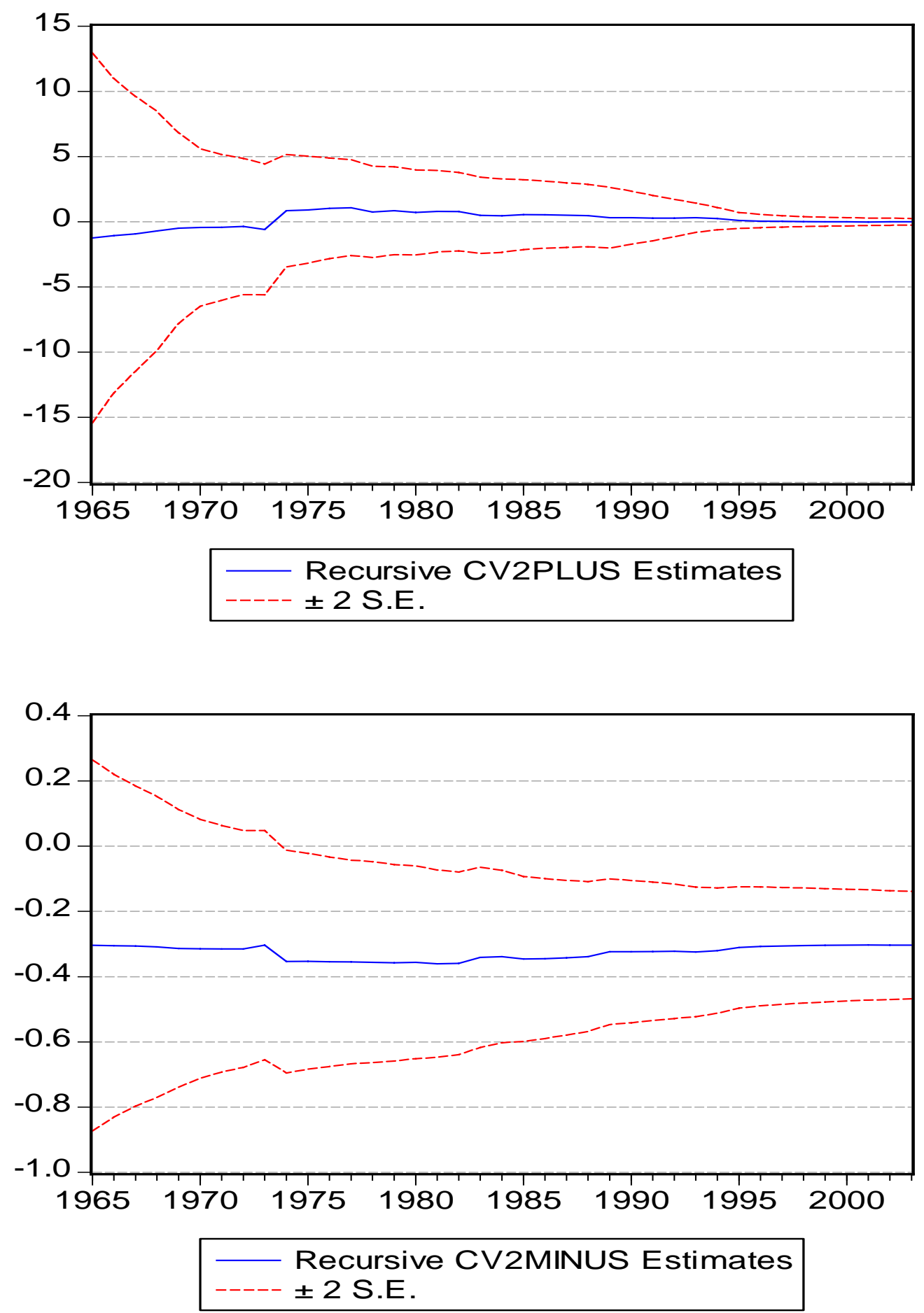
Table 1. Long-run analysis

\begin{tabular}{|cccccccc|}
\hline & & $\lambda$-max & \multicolumn{5}{c|}{$\lambda$-trace } \\
$\mathrm{H}_{0}$ & $\mathrm{H}_{1}$ & Stat. & $95 \%$ & $\mathrm{H}_{0}$ & $\mathrm{H}_{1}$ & Stat. & $95 \%$ \\
$\mathrm{r}=0$ & $\mathrm{r}=1$ & 75.17 & 22.29 & $\mathrm{r}=0$ & $\mathrm{r} \geq 1$ & 96.52 & 35.19 \\
$\mathrm{r} \leq 1$ & $\mathrm{r}=2$ & 18.56 & 15.89 & $\mathrm{r} \leq 1$ & $\mathrm{r} \geq 2$ & 21.34 & 20.26 \\
$\mathrm{r} \leq 2$ & $\mathrm{r}=3$ & 2.78 & 9.16 & $\mathrm{r} \leq 2$ & $\mathrm{r}=3$ & 2.78 & 9.16 \\
\hline
\end{tabular}

Table 2. Error correction models for local expenditure*

\begin{tabular}{l|ccc}
\hline & (i) & (ii) & (iii) \\
\hline & & & \\
$C$ & $0.26(.00)$ & $0.07(.00)$ & $.08(.00)$ \\
$\Delta T R$ & $0.10(.01)$ & $0.11(.00)$ & $.11(.03)$ \\
CV1 & $-0.14(.00)$ & - & $-.12(.03)$ \\
CV1PLUS(-1) & - & $-.08(.09)$ & - \\
CV1MINUS(-1) & - & $-.22(.00)$ & - \\
CV1 ${ }^{2}(-1)$ & - & - & $.13(.15)$ \\
CV1 $^{3}(-1)$ & - & - & $-.16(.47)$ \\
& & & \\
Adjust. R & .47 & .49 & .49 \\
S.e. & .05 & .05 & .05 \\
Breusch-Godfrey & .83 & .62 & .89 \\
Heteroscedasticity & .02 & .14 & .81 \\
RESET & .19 & .54 & .73 \\
\hline
\end{tabular}

$\left(^{\star}\right)$ Figures in parentheses are the p-values. Adjust. $R^{2}$ is the adjusted coefficient of determination of the regression. RESET is the Ramsey's RESET test. (includes the square of the fitted value). 
Table 3. BDS test on the residuals of the local expenditure linear $\mathrm{ECM}^{1}$

\begin{tabular}{|l|l|l|l|}
\hline & $\varepsilon=0.025$ & $\varepsilon=0.05$ & $\varepsilon=0.10$ \\
\hline$M$ & & & \\
\hline 2 & & & \\
\hline 3 & 0.94 & 0.53 & 0.27 \\
\hline 4 & 0.10 & 0.33 & 0.06 \\
\hline 5 & 0.00 & 0.03 & 0.31 \\
\hline
\end{tabular}

Table 4. Error correction models for local taxation.

\begin{tabular}{l|ccc}
\hline & (i) & (ii) & (iii) \\
\hline C & & & \\
$\Delta T R$ & $.21(.00)$ & $.09(.41)$ & $.11(.00)$ \\
CV2(-1) & $-.61(.08)$ & $-.41(.25)$ & $-.38(.17)$ \\
CV2PLUS(-1) & $-.20(.00)$ & - & $-.13(.03)$ \\
CV2MINUS(-1) & - & $-.01(.95)$ & - \\
CV2 ${ }^{2}(-1)$ & - & $-.30(.00)$ & - \\
CV2 $^{3}(-1)$ & - & - & $.06(.02)$ \\
& - & - & $.01(.79)$ \\
Adjust. R & & & \\
S.e. & .18 & .21 & .20 \\
Breusch-Godfrey & .45 & .43 & .43 \\
Heteroscedasticity & .12 & .30 & .28 \\
RESET & .00 & .00 & .00 \\
\hline
\end{tabular}

\footnotetext{
${ }^{1}$ The BDS test statistic tests the null hypothesis that a series is i.i.d. against the alternative of realization from an unspecified non-linear process. $m$ is the embedding dimension and $\varepsilon$ equals $0.5 \sigma_{\mathrm{L}}, 1.0 \sigma_{\mathrm{L}}$ and $2.0 \sigma_{\mathrm{L}}$, respectively, where $\sigma_{\mathrm{L}}=0.05$ is the standard deviation of the residuals. Given that the choices of $m$ and $\varepsilon$ are crucial for the power of the test, we report the results for different plausible values of $m$ and $\varepsilon$ as suggested by Brock, Hsieh and LeBaron (1991). Only the bootstrapped $p$ values are reported.
} 
Table 5. BDS test on the residuals of the local taxation linear ECM.

\begin{tabular}{|l|c|c|c|}
\hline & $\varepsilon=0.225$ & $\varepsilon=0.45$ & $\varepsilon=0.90$ \\
\hline$M$ & & & \\
\hline 2 & & & \\
\hline 3 & 0.00 & 0.00 & 0.00 \\
\hline 4 & 0.00 & 0.00 & 0.00 \\
\hline 5 & 0.00 & 0.01 & 0.00 \\
\hline
\end{tabular}

Notes: see table (2c), with $\sigma_{\mathrm{L}}=0.45$. 


\section{CESifo Working Paper Series}

for full list see www.cesifo-group.org/wp

(address: Poschingerstr. 5, 81679 Munich, Germany, office@cesifo.de)

2489 Mikael Elinder, Henrik Jordahl and Panu Poutvaara, Selfish and Prospective: Theory and Evidence of Pocketbook Voting, December 2008

2490 Maarten Bosker and Harry Garretsen, Economic Geography and Economic Development in Sub-Saharan Africa, December 2008

2491 Urs Fischbacher and Simon Gächter, Social Preferences, Beliefs, and the Dynamics of Free Riding in Public Good Experiments, December 2008

2492 Michael Hoel, Bush Meets Hotelling: Effects of Improved Renewable Energy Technology on Greenhouse Gas Emissions, December 2008

2493 Christian Bruns and Oliver Himmler, It's the Media, Stupid - How Media Activity Shapes Public Spending, December 2008

2494 Andreas Knabe and Ronnie Schöb, Minimum Wages and their Alternatives: A Critical Assessment, December 2008

2495 Sascha O. Becker, Peter H. Egger, Maximilian von Ehrlich and Robert Fenge, Going NUTS: The Effect of EU Structural Funds on Regional Performance, December 2008

2496 Robert Dur, Gift Exchange in the Workplace: Money or Attention?, December 2008

2497 Scott Alan Carson, Nineteenth Century Black and White US Statures: The Primary Sources of Vitamin D and their Relationship with Height, December 2008

2498 Thomas Crossley and Mario Jametti, Pension Benefit Insurance and Pension Plan Portfolio Choice, December 2008

2499 Sebastian Hauptmeier, Ferdinand Mittermaier and Johannes Rincke, Fiscal Competition over Taxes and Public Inputs: Theory and Evidence, December 2008

2500 Dirk Niepelt, Debt Maturity without Commitment, December 2008

2501 Andrew Clark, Andreas Knabe and Steffen Rätzel, Boon or Bane? Others' Unemployment, Well-being and Job Insecurity, December 2008

2502 Lukas Menkhoff, Rafael R. Rebitzky and Michael Schröder, Heterogeneity in Exchange Rate Expectations: Evidence on the Chartist-Fundamentalist Approach, December 2008

2503 Salvador Barrios, Harry Huizinga, Luc Laeven and Gaëtan Nicodème, International Taxation and Multinational Firm Location Decisions, December 2008

2504 Andreas Irmen, Cross-Country Income Differences and Technology Diffusion in a Competitive World, December 2008 
2505 Wenan Fei, Claude Fluet and Harris Schlesinger, Uncertain Bequest Needs and LongTerm Insurance Contracts, December 2008

2506 Wido Geis, Silke Uebelmesser and Martin Werding, How do Migrants Choose their Destination Country? An Analysis of Institutional Determinants, December 2008

2507 Hiroyuki Kasahara and Katsumi Shimotsu, Sequential Estimation of Structural Models with a Fixed Point Constraint, December 2008

2508 Barbara Hofmann, Work Incentives? Ex Post Effects of Unemployment Insurance Sanctions - Evidence from West Germany, December 2008

2509 Louis Hotte and Stanley L. Winer, The Demands for Environmental Regulation and for Trade in the Presence of Private Mitigation, December 2008

2510 Konstantinos Angelopoulos, Jim Malley and Apostolis Philippopoulos, Welfare Implications of Public Education Spending Rules, December 2008

2511 Robert Orlowski and Regina T. Riphahn, The East German Wage Structure after Transition, December 2008

2512 Michel Beine, Frédéric Docquier and Maurice Schiff, International Migration, Transfers of Norms and Home Country Fertility, December 2008

2513 Dirk Schindler and Benjamin Weigert, Educational and Wage Risk: Social Insurance vs. Quality of Education, December 2008

2514 Bernd Hayo and Stefan Voigt, The Relevance of Judicial Procedure for Economic Growth, December 2008

2515 Bruno S. Frey and Susanne Neckermann, Awards in Economics - Towards a New Field of Inquiry, January 2009

2516 Gregory Gilpin and Michael Kaganovich, The Quantity and Quality of Teachers: A Dynamic Trade-off, January 2009

2517 Sascha O. Becker, Peter H. Egger and Valeria Merlo, How Low Business Tax Rates Attract Multinational Headquarters: Municipality-Level Evidence from Germany, January 2009

2518 Geir H. Bjønnes, Steinar Holden, Dagfinn Rime and Haakon O.Aa. Solheim, ,Large’ vs. ,Small' Players: A Closer Look at the Dynamics of Speculative Attacks, January 2009

2519 Jesus Crespo Cuaresma, Gernot Doppelhofer and Martin Feldkircher, The Determinants of Economic Growth in European Regions, January 2009

2520 Salvador Valdés-Prieto, The 2008 Chilean Reform to First-Pillar Pensions, January 2009 
2521 Geir B. Asheim and Tapan Mitra, Sustainability and Discounted Utilitarianism in Models of Economic Growth, January 2009

2522 Etienne Farvaque and Gaël Lagadec, Electoral Control when Policies are for Sale, January 2009

2523 Nicholas Barr and Peter Diamond, Reforming Pensions, January 2009

2524 Eric A. Hanushek and Ludger Woessmann, Do Better Schools Lead to More Growth? Cognitive Skills, Economic Outcomes, and Causation, January 2009

2525 Richard Arnott and Eren Inci, The Stability of Downtown Parking and Traffic Congestion, January 2009

2526 John Whalley, Jun Yu and Shunming Zhang, Trade Retaliation in a Monetary-Trade Model, January 2009

2527 Mathias Hoffmann and Thomas Nitschka, Securitization of Mortgage Debt, Asset Prices and International Risk Sharing, January 2009

2528 Steven Brakman and Harry Garretsen, Trade and Geography: Paul Krugman and the 2008 Nobel Prize in Economics, January 2009

2529 Bas Jacobs, Dirk Schindler and Hongyan Yang, Optimal Taxation of Risky Human Capital, January 2009

2530 Annette Alstadsæter and Erik Fjærli, Neutral Taxation of Shareholder Income? Corporate Responses to an Announced Dividend Tax, January 2009

2531 Bruno S. Frey and Susanne Neckermann, Academics Appreciate Awards - A New Aspect of Incentives in Research, January 2009

2532 Nannette Lindenberg and Frank Westermann, Common Trends and Common Cycles among Interest Rates of the G7-Countries, January 2009

2533 Erkki Koskela and Jan König, The Role of Profit Sharing in a Dual Labour Market with Flexible Outsourcing, January 2009

2534 Tomasz Michalak, Jacob Engwerda and Joseph Plasmans, Strategic Interactions between Fiscal and Monetary Authorities in a Multi-Country New-Keynesian Model of a Monetary Union, January 2009

2535 Michael Overesch and Johannes Rincke, What Drives Corporate Tax Rates Down? A Reassessment of Globalization, Tax Competition, and Dynamic Adjustment to Shocks, February 2009

2536 Xenia Matschke and Anja Schöttner, Antidumping as Strategic Trade Policy Under Asymmetric Information, February 2009 
2537 John Whalley, Weimin Zhou and Xiaopeng An, Chinese Experience with Global 3G Standard-Setting, February 2009

2538 Claus Thustrup Kreiner and Nicolaj Verdelin, Optimal Provision of Public Goods: A Synthesis, February 2009

2539 Jerome L. Stein, Application of Stochastic Optimal Control to Financial Market Debt Crises, February 2009

2540 Lars P. Feld and Jost H. Heckemeyer, FDI and Taxation: A Meta-Study, February 2009

2541 Philipp C. Bauer and Regina T. Riphahn, Age at School Entry and Intergenerational Educational Mobility, February 2009

2542 Thomas Eichner and Rüdiger Pethig, Carbon Leakage, the Green Paradox and Perfect Future Markets, February 2009

2543 M. Hashem Pesaran, Andreas Pick and Allan Timmermann, Variable Selection and Inference for Multi-period Forecasting Problems, February 2009

2544 Mathias Hoffmann and Iryna Shcherbakova, Consumption Risk Sharing over the Business Cycle: the Role of Small Firms' Access to Credit Markets, February 2009

2545 John Beirne, Guglielmo Maria Caporale, Marianne Schulze-Ghattas and Nicola Spagnolo, Volatility Spillovers and Contagion from Mature to Emerging Stock Markets, February 2009

2546 Ali Bayar and Bram Smeets, Economic and Political Determinants of Budget Deficits in the European Union: A Dynamic Random Coefficient Approach, February 2009

2547 Jan K. Brueckner and Anming Zhang, Airline Emission Charges: Effects on Airfares, Service Quality, and Aircraft Design, February 2009

2548 Dolores Messer and Stefan C. Wolter, Money Matters - Evidence from a Large-Scale Randomized Field Experiment with Vouchers for Adult Training, February 2009

2549 Johannes Rincke and Christian Traxler, Deterrence through Word of Mouth, February 2009

2550 Gabriella Legrenzi, Asymmetric and Non-Linear Adjustments in Local Fiscal Policy, February 2009 